\title{
Važnost provjere sterilnosti hranjivih podloga za identifikaciju mikroorganizama prije upotrebe $u$ mikrobiološkom laboratoriju
}

\author{
1 Adis Hrvačić \\ 1 Zavod za javno zdravstvo SBK/KSB-a, Travnik
}

\section{Sažetak}

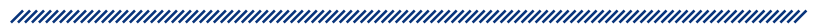

Mikrobiološka kontaminacija hranjivih podloga koje se upotrebljavaju za uzgajanje mikroorganizama prilično je česta u mikrobiološkim laboratorijima. Tijekom pripreme hranjivih podloga za uzgoj i izolaciju čistih bakterijskih kultura vjerojatnost kontaminacije velika je ili zbog neadekvatne sterilizacije, nepravilnog rukovanja ili neadekvatne kontrole uvjeta pohrane i provjere roka trajanja. Pripremljene ploče ne smiju se odmah upotrebljavati ili čuvati na niskoj temperaturi dok se ne testiraju na sterilnost. Provjera sterilnosti vrlo je važan segment prije upotrebe ploča za mikrobiološke postupke i procedure i jedan od glavnih faktora koji utječe na validnost rezultata ispitivanja u mikrobiološkom laboratoriju.

Cilj je rada uspostaviti kriterije odbacivanja kontaminiranih ploča. Pripremljena su tri seta ploča hranjivih podloga koji su tijekom 18 do 24 sata inkubirani na sobnoj temperaturi za provjeru sterilnosti. Procjena kontaminacije: porast kolonije na površini ili ispod nje. Inkubacija ploča produžena je za još jedan dan za razvoj kontaminacije na pločama na kojima nije bilo porasta kolonija prvog dana.

Rezultati su otkrili da su u dvije skupine pronađene dvije vrste kontaminacije. Prvi set ploča ima kolonije na površini i kontaminacija nije pronađena drugog dana na nekontaminiranim pločama, što ukazuje na to da bi se kontaminacija mogla dogoditi tijekom postupaka nepravilnog rukovanja pločama. Druga skupina ima kolonije ispod površine i zagađenje se drugog dana razvijalo i u nekontaminiranim pločama zbog nepravilne sterilizacije staklenog posuđa ili nepravilne sterilizacije hranjivih medija.

Uviđajući važnost provjere sterilnosti prije upotrebe hranjivih podloga za kultiviranje mikroorganizama od interesa, preporučeno je da se ploče kojima je potvrđena sterilnost mogu upotrebljavati za daljnje mikrobiološke procedure, dok je za sve ostale setove kontaminiranih ploča potrebno uspostaviti kriteriji odbacivanja bez obzira na to koja je vrsta kontaminacije pronađena i kako je nastala.

Ključne riječi: mikrobiološka kontaminacija, sterilnost, mikroorganizmi, laboratorij

Datum primitka: 11.07.2020.

Datum prihvaćanja: 01.09.2020.

https://doi.org/10.24141/1/6/2/12

Adresa za dopisivanje:

Adis Hrvačić

A: Zavod za javno zdravstvo SBK/KSB,

Bolnička 1,72270 Travnik, Bosna i Hercegovina

E-pošta: adishrvacic@gmail.com

T: +38730511394 


\section{Uvod}

Mikroorganizmi koji su od interesa za uzgoj i izolaciju u mikrobiološkom laboratoriju sveprisutne su prirode i široke slobode rasprostranjenosti kako u našem prirodnom okolišu tako i u mikroklimi koja vlada u okruženju u laboratorijima. Podloge za mikrobnu kulturu mogu biti različitog tipa, ovisno o nutritivnim potrebama rasta mikroorganizama, te služe za izolaciju uzgoj i diferencijaciju nepoznatih mikroorganizama. I najbolji su medij za primjenu u obliku čvrstog agara, koji služe za uzgoj i skladištenje pod određenim uvjetima na određeni rok čuvanja. ${ }^{1}$ Trenutačna baza znanja o mikrobnim medijima rasta ograničavajući je faktor u kultivaciji različitih mikroorganizama, ali velike površine ovih agarnih ploča daju dobru osnovu za njihovo poboljšanje i što bolju kultivaciju i identifikaciju mikroorganizama važnih za ispitne laboratorije. ${ }^{2}$ Faktori okoline, kao i pH-vrijednost, temperatura, osmotski tlak, vlaga i ostalo imaju utjecaj kao osnova za poticanje razvoja odgovarajućeg medija sposobnog podržati rast željenih mikroorganizama bez promjene ravnoteže mikrobne zajednice i tehnoloških performansi. ${ }^{3}$

Jedna od bitni stavki u pripremi čvrstih hranjivih podloga jest sterilnost medija nakon receptualne pripreme, a takve performanse postižu se odgovarajućom sterilizacijom kako pripremljenih hranjivih podloga tako i staklenog posuđa koje se upotrebljava u postupku pripreme. Sterilizacija je kontrolirana inaktivacijom bakterija koje stvaraju spore (Bacillus cereus i Geobacillus stearothermophilus) za proizvodnju sterilnog proizvoda i jedan je od alata potvrde pravilne sterilizacije hranjivih medija. ${ }^{4}$ Pravilna manipulacija hranjivim medijima za izolaciju bakterija okosnica je pripreme i smanjenja stupnja kontaminacije. Isto tako, utjecaji mikroorganizama iz zraka, laboratorijskih površina, stolova i ostale opreme koja se upotrebljava kritične su točke koje su važne za kontaminaciju hranjivih medija. Uspjeh sprječavanja kontaminacije oslanja se na sposobnost da se steriliziraju radne površine i oprema, kao i da spriječi kontakt sterilnih instrumenata i otopina s nesterilnim površinama. ${ }^{5}$

Ploče poslije procesa izlijevanja i pripreme ne smiju se odmah upotrebljavati za proces rada dok se ne provede mikrobiološka kontrola njihove sterilnosti. Ploče se čuvaju u inkubatoru 18 do $24 \mathrm{~h}$ na $37{ }^{\circ} \mathrm{C}$. Postoje različite metode za sustavno provjeravanje svih tih parametara. Pažljiv učinak kontrole kvalitete kulturnih medija može osigurati preciznost u izvještavanju. ${ }^{6}$ Interna kontrola za detekciju kontaminiranih hranjivih podloga uspostavlja interne kriterije za odbacivanje kontaminiranih ploča iz procesa upotrebe i odabir samo onih ploča koje su prošle test na sterilnost, kao i ostale karakteristike kao što su konzistencija, boja i onečišćenje. ${ }^{7}$

\section{Materijali i metode}

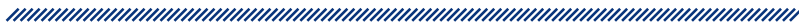

Ovaj je rad načinjen opservacijski u svrhu detekcije kontaminacije podloga koje se upotrebljavaju pri pripremi ploča za sanitarnu mikrobiologiju u svakodnevnom radu.

\section{Priprema ploča za upotrebu}

Podloge se pripremaju prema našoj proceduri za pripremu podloga (UP14_10). Upute se primjenjuje laboratorijima za sanitarnu i humanu mikrobiologiju ZZJZ-a Travnik za pripremu kvalitetnih mikrobioloških podloga za uzgoj patogenih i uvjetno patogenih bakterija u dijelu humane mikrobiologije kao sastavni dio dijagnostičkih postupaka i za uzgoj indikatora mikrobiološke kontaminacije voda i namirnica i brisova površina u sastavu sanitarne mikrobiologije. Podloge se pripravljaju uz strogo pridržavanje principa asepse i dostavljene recepture proizvođača koji svojim certifikatima jamči validnost podloge. Nakon postupka sterilizacije našim eksterno umjerenim automatskim autoklavima i setom za biološku kontrolu suhe sterilizacije B.atrophaeus ATCC 9372, log 6 s Releasat Mediumom i testnim sustavom za biološku kontrolu suhe i vlažne sterilizacije 105 G. stearothermophilus + 106 B. atrophaeus, ProTest ampule za biološku kontrolu parne sterilizacije na 121 i 134105 G. stearothermophilus, ploče se pripremaju u prostoru za razlijevanje podloga s UV svjetiljkama za sterilizaciju zraka i prostora.

\section{Provjera sterilnosti}

Sve pripremljene ploče uključuju se u proces provjere prema proceduri PR37_Osiguranje_kvaliteta_rezultata_ispitivanja i primjenu izvještaja Izvjestaj_unutarnje ispitivanje kvalitete medija kulture (slika 1), nakon toga se ploče čuvaju u inkubatoru temperaturi 18 do $24 \mathrm{~h}$ na $37^{\circ} \mathrm{C}$ radi provjere sterilnosti - mikrobiološka kontaminacija. Osim toga, provodi se fizičko-kemijska kontrola kvalitete ploča, mikrobiološka produktivnost, mikrobiološka selektivnost, sve ono što može utjecati na rezultate ispitivanja. 


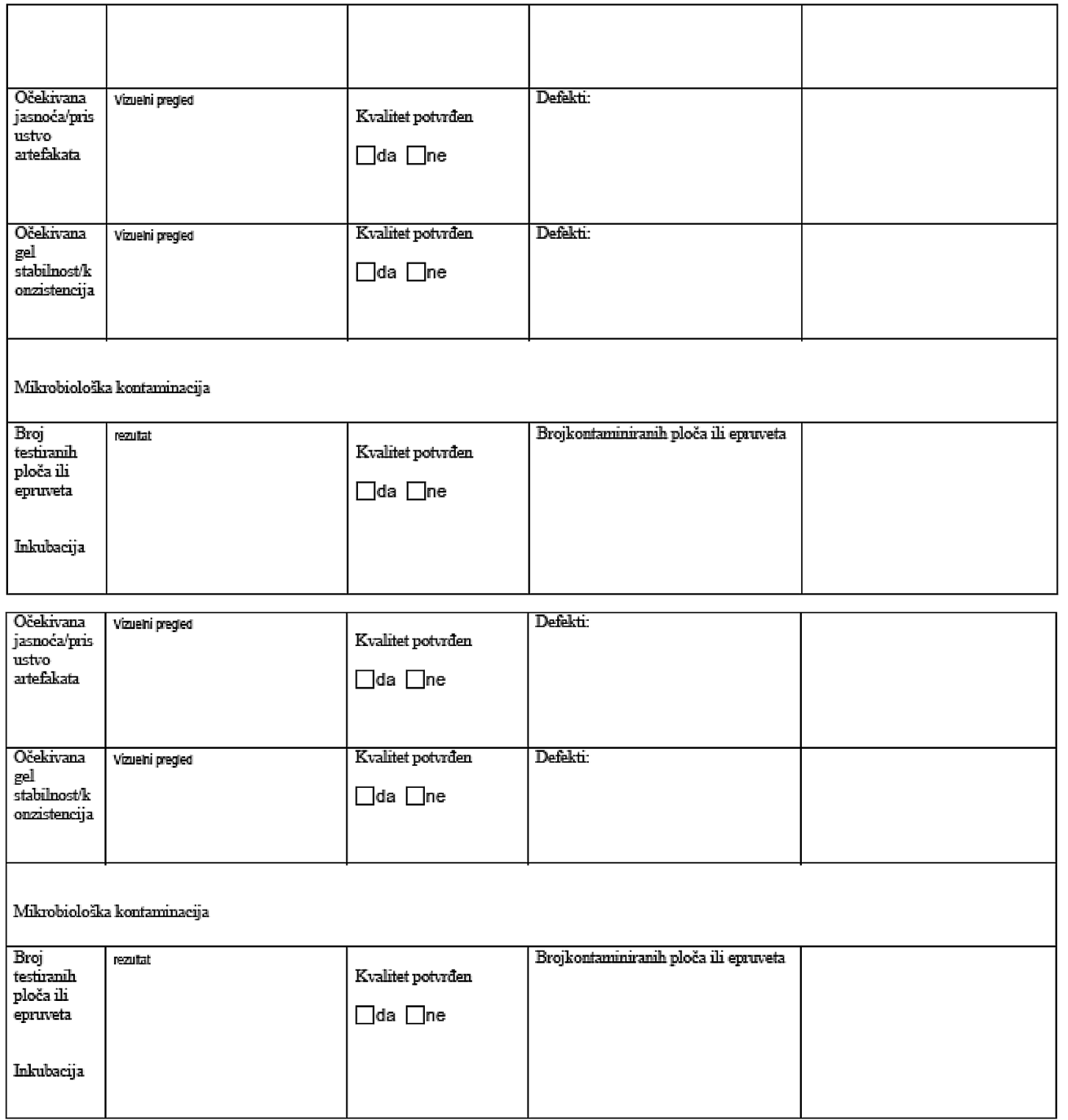

\begin{tabular}{|c|c|c|c|c|}
\hline \multicolumn{2}{|c|}{ Mikrobioloska produltivnost } & metoda kontrole: & $\square$ kvantitativni & hvalitativni \\
\hline $\begin{array}{l}\text { Balkterija: } \\
\text { Inkubacija: } \\
\text { Referentmi } \\
\text { medium }\end{array}$ & kiteri: & Remulltat: & $\begin{array}{l}\text { Kvalitet poturden } \\
\square \text { da } \square \text { ne }\end{array}$ & \\
\hline Milrobiolo: & a seleltivinost: & metoda kontrole: & $\square$ kwantitativni & Mralitativin \\
\hline $\begin{array}{l}\text { Ocekivama } \\
\text { gel } \\
\text { stabilnostk } \\
\text { onciotencija }\end{array}$ & Vouehi pregled & Rerultat: & $\begin{array}{l}\text { Kvalitet poturten } \\
\square \text { da } \square \text { ne }\end{array}$ & \\
\hline
\end{tabular}

Slika 1. IZV_PR37_01_Izvjestaj_unutarnje ispitivanje kvalitete medija kulture, laboratorij ZZJZ-a Travnik 


\section{Priprema setova za kontrolu mikrobiološke kontaminacije}

Za prvi set mikrobioloških ploča, set A, pripremljeno je 30 ploča za inkubaciju. Poštovani su svi uvjeti proceduralne pripreme ploča s kontrolom svih kritičnih točaka u pripremi (priprema, sterilizacija kontrola, validacija). Za drugi set ploča, set $B$, pripremljeno je 30 ploča, ali namjerno provocirajući neadekvatne uvjete pripreme, kao što je neadekvatno vrijeme sterilizacije same podloge (pozitivna biološka kontrola) ili nesterilno stakleno posuđe. Treći set ploča, set C, pripremljen je prilikom rukovanja pločama i izvršena je namjerna kontaminacija kontrolnim sojem ATCC $^{\text {TM }} 6538$ Staphylococcus aureus subsp. aureus.

\section{Detekcija kontaminacije prije upotrebe ploča}

Nakon propisanog vremena inkubacije, a prije upotrebe podloga, detektiraju se ploče s mikrobiološkom kontaminacijom i dokumentiraju na sljedeći način:
a) nema mikrobiološke kontaminacije ploča
b) kontaminacija na površini ploča
c) porast bakterija ispod površine ploča.

\section{Rezultati}

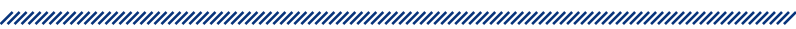

$U$ setu A nakon inkubacije nije bilo mikrobioloških kontaminiranih ploča. U setu B kontaminacija se pojavila na 8 od $30(26,7 \%)$ ploča. U setu C kontaminacija se pojavila na $23(76,7 \%)$ od 30 ploča.

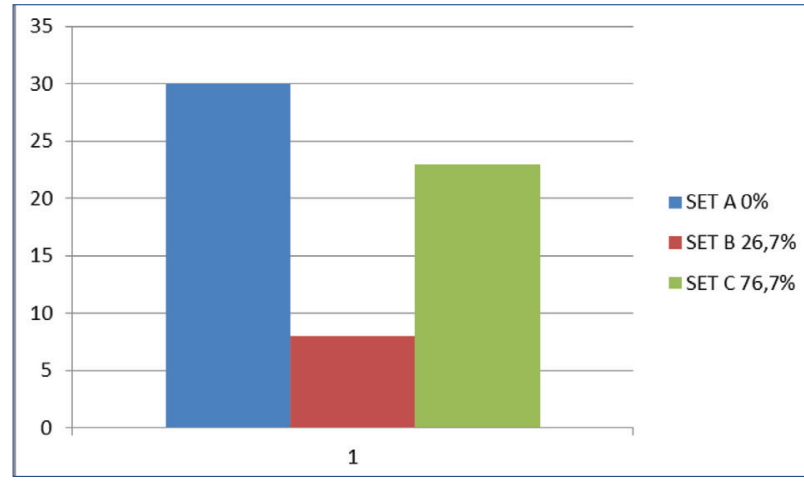

Grafikon 1. Broj i postotak kontaminiranih setova ploča

U setu $C$, od 23 kontaminirane ploče, u 10 je ploča $(43,47 \%)$ kontaminacija bila ispod površine agara, u osam ploča kontaminacija se pojavila na površini podloge i u pet $(21,73 \%)$ ploča bile su obje vrste kontaminacije, na površini $\mathrm{i}$ ispod podloge.

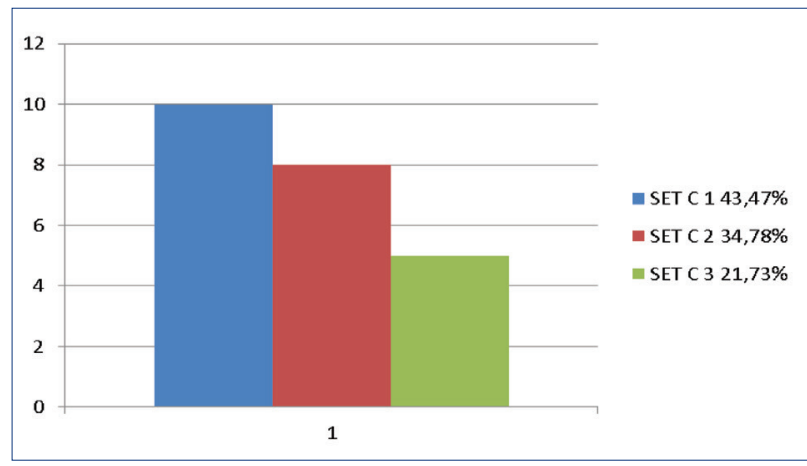

Grafikon 2. Lokacija, broj i postotak kontaminiranih ploča - set C

\begin{tabular}{|c|c|c|c|c|c|c|}
\hline Set & $\begin{array}{l}\text { Kultura } \\
\text { medija }\end{array}$ & $\begin{array}{c}\text { Broj } \\
\text { pripremljenih } \\
\text { ploča }\end{array}$ & Inkubacija & $\begin{array}{l}\text { Broj i postotak } \\
\text { kontaminiranih } \\
\text { ploča }\end{array}$ & $\begin{array}{c}\text { Lokacija } \\
\text { kontaminacije }\end{array}$ & $\begin{array}{l}\text { Kriterij procjena } \\
\text { provjere }\end{array}$ \\
\hline A & \multirow{5}{*}{$\begin{array}{l}\text { Krvni } \\
\text { hranjivi } \\
\text { agar }\end{array}$} & 30 & $\begin{array}{c}18-24 \mathrm{~h} \text { na } \\
37^{\circ} \mathrm{C}\end{array}$ & $30(0)$ & nema porasta & prihvatljive za upotrebu \\
\hline B & & 30 & $\begin{array}{c}18-24 \mathrm{~h} \text { na } \\
37^{\circ} \mathrm{C}\end{array}$ & $8(26,7)$ & površina ploča & $\begin{array}{c}\text { prihvatljive } \\
\text { nekontaminirane ploče }\end{array}$ \\
\hline \multirow{3}{*}{ C } & & \multirow{3}{*}{30} & \multirow{3}{*}{$\begin{array}{c}18-24 \mathrm{~h} \text { na } \\
37^{\circ} \mathrm{C}\end{array}$} & \multirow{3}{*}{$23(76,7)$} & $\begin{array}{c}10(43,47) \text { ispod } \\
\text { površine }\end{array}$ & \multirow{3}{*}{ sve su ploče odbačene } \\
\hline & & & & & $\begin{array}{c}8(34,78) \text { na } \\
\text { površini }\end{array}$ & \\
\hline & & & & & $5(21,73)$ obje & \\
\hline
\end{tabular}




\section{Rasprava}

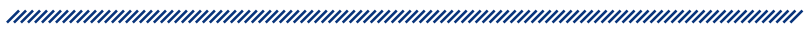

U ovom radu želja je bila prikazati važnost primjene uspostavljenih kriterija odbacivanja kontaminiranih podloga u sklopu interne kontrole kvalitete koja je bila simulacija neadekvatnih uvjeta kako pripreme tako i svih nepovoljnih unutrašnjih i vanjskih faktora koje imamo u mikrobiološkom laboratoriju. Sam standard BAS/EN ISO/IEC 11133/A1:2019 mikrobiologija hrane, hrane za životinje i vode - Priprema, proizvodnja, skladištenje i testiranje podloga za kulturu ${ }^{8}$ definirao je protokole pripreme koji u našim uvjetima moraju biti prilagođeni našim potrebama, odnosno modificirani koliko to struka dozvoljava. Bakterije su razvile mnogo različitih mehanizama za opstanak u okruženjima sa smanjenim hranjivim tvarima i oštrim okruženjima. Temperatura je jedan od faktora koji utječe na održavanje sterilnosti ploča za razvoj bakterija za određene mikroorganizme. ${ }^{9}$

Preporučuje se rad na pločama kulture za mikrobiološku upotrebu u „svježem stanju”, to jest nakon kontrole sterilnosti i ostalih parametara mikrobioloških internih kontrola. Preporuka je da se kontrolne ploče za rast mikroorganizama što prije utroše u rutinskim analizama, odnosno da se plansko uzorkovanje materijala na terenu planira s unaprijed najavljenim i projiciranim potrebama za mikrobiološku pripremu potrebnih resursa svakog laboratorija koji su uskladišteni na niskim temperaturama. ${ }^{10}$ Držanje mikrobioloških ploča na niskom temperaturama tijekom dužeg perioda nije preporučljivo zato što je moguć rast psihrofilnih organizama. Čini se da se njihova adaptacija oslanja na veću fleksibilnost ključnih dijelova molekularne strukture za preživljavanje i širenje se na niskim temperaturama, što je jedna od opasnosti kontaminacije već gotovih i testiranih ploča u uvjetima čuvanja u hladnjacima na niskim temperaturama. ${ }^{11}$

Zato naš laboratorij redovito analizira i potvrđuje rok trajanja pripremljenih agarnih ploča, ali u biti smo skloniji propisivati manje rokove za podloge u svojim internim kontrolama kako bismo smanjili ovu vrstu moguće kontaminacije. Batarilo i suradnici (2011) analizirali su 2558 uzoraka u periodu od tri godine, broj ploča s porastom većim od 50 cfu bio je statistički značajno manji u drugoj i trećoj godini praćenja u odnosu na prvu godinu. ${ }^{12}$ To nas upućuje na to da se dugoročnim provođenjem strožih kriterija koje propisuje mikrobiološki laboratorij smanjuje i razna kontaminacije. Kvalitetna priprema agarnog medija inače u laboratorijima ovisi o nekoliko faktora: kvaliteti dehidriranih medija, kvaliteti Petrijevih ploča, kemikalija i raznih suplemenata koji se primjenjuju kao dodaci, krvnog seruma, vode itd. Pravilnim praćenjem ovih parametara kontaminacija se može smanjiti i do $50 \% .{ }^{13}$ Nepravilna sterilizacija, od staklenog posuđa do podloge medija, može pospješiti kontaminaciju i prisutnost nepoželjnih mikroorganizama te utjecati na rezultate ispitivanja. ${ }^{14}$ Higijenski nadzor površina u laboratorijima nužan je za osiguranje kvalitete održavanja čistoće prostora laboratorija. Metoda brisa jest standardizirana metoda uzorkovanja površine i inače ukupan broj bakterija i ukupan broj Enterobacteriaceae procjenjuju rizik od kontaminacije tijekom pripreme agarnih ploča. ${ }^{14}$

Osim toga, treba pooštriti kriterije i dodatno planirati sve aspekte mogućih rizika koji mogu utjecati na rezultate ispitivanja u mikrobiološkom laboratoriju. Nasuprot standardnoj provjeri na sterilnost samo nekoliko ploča iz pripremljene sarže ${ }^{15}$ agarnih ploča, predlažemo provjeru svih ploča na mikrobiološku kontaminaciju, kao i na ostale pokazatelja unutrašnje kontrole unutar 18 do 24 sata koje radimo u našem mikrobiološkom laboratoriju. Svaki laboratorij mora imati procedure (PR) kontrole kvalitete predanalitičkih, analitičkih i poslijeanalitičkih faza mikrobioloških postupaka i mora biti uključen u PR i vlastite postupke koji će propisivati rizike kod uspostavljanja kriterija odbacivanja kontaminiranih ploča, a odnose se na kontrolu pogrešaka u izvođenju testova i provjeru rezultata ispitivanja na koje bi ovaj proces u konačnici mogao utjecati.

\section{Zaključak}

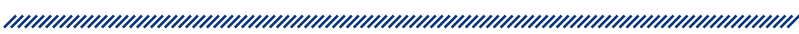

Iz rezultata ovog rada može se zaključiti da bi svi mikrobiološki laboratoriji obvezno trebali slijediti točke standarda BAS EN ISO/IEC 17025:2018 - Opšti zahtjevi za kompetentnost ispitnih i kalibracionih laboratorija, BAS EN ISO 15189:2018 - Medicinski laboratoriji - Zahtjevi za kvalitet i kompetentnost, kako bi se zadovoljili ovi kriteriji provjere ploča prije njihove upotrebe, a posebno medicinski i klinički laboratoriji, o čijim rezultatima dalje ovisi zdravstveno stanje i postavljanje dijagnoze pacijenata ili korisnika njihovih usluga. Održavanje ovih kriterija zahtijeva stalni monitoring, analize i nadgledanje upravljanja mikrobiološkom kontaminacijom, od 
dizajna nekontaminiranih prostora, zaštitne opreme za aseptično rukovanje pločama do procjene stanja okoliša, planova dezinfekcije, čišćenja, prakse fumigacije zraka za sanitarnu zaštitu, monitoringa opreme itd. Otklanjanjem ovih rizičnih faktora samo unaprjeđenje ovih postupaka daje mogućnost nesmetane mikrobiološke fleksibilnosti za izolaciju mikroorganizama od interesa za svaki mikrobiološki laboratorij s adekvatnom provjerom agarnih ploča za upotrebu u laboratoriju.

U skladu s etičkim standardima.

\section{Zahvala}

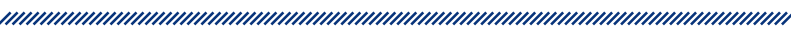

Autor zahvaljuje rukovodstvu Zavoda za javno zdravstvo SBK/KSB-a, Travnik za dozvolu izvršenja i objavljivanja ovog rada.

\section{Sukob interesa}

Nema.

\section{Referencije}

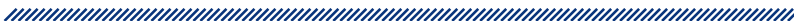

1. Sudo $\mathrm{K}$ et al. Viability of meticillin-resistant Staphylococcus aureus after long-term storage on Dorset egg medium. J Med Microbiol. 2016; 65(12): 1540-1541. https:// doi.org/10.1099/jmm.0.000364

2. Basu Setal. Evolution of bacterial and fungal growth media. Bioinformation. 2015; 11(4): 182. 10.6026/97320630011182

3. Chessa $L$ et al. Effect of growth media on natural starter culture composition and performance evaluated with a polyphasic approach. International Journal of Dairy Technology. 2019; 72(1): 152-158. doi.org/10.1111/14710307.12571

4. Wimalaratne SK, Farid MM. Pressure assisted thermal sterilization. Food and Bioproducts Processing. 2008; 86(4): 312-316. doi.org/10.1016/j.fbp.2007.08.001

5. Sanders ER. Aseptic laboratory techniques: plating methods. Journal of Visualized Experiments. 2012; 63: e3064. doi: 10.3791/3064

6. Basu S, Pal A, Desai PK. Quality control of culture media in a microbiology laboratory. Indian J Med Microbiol. 2005; 23(3): 159. DOI: 10.4103/0255-0857.16586

7. Krisher K et al. Quality Control for Commercially prepared Microbiological Culture Media. Wayne, Pa.: NCCLS; 2004.

8. ISO 11133:2014. Microbiology of food, animal feed and water- Preparation, production, storage and performance testing of culture media. 2014.

9. Navarro Llorens JM, Tormo A, Martínez-García E. Stationary phase in gram-negative bacteria. FEMS Microbiol Rev. 2010; 34(4): 476-495. doi.org/10.1111/j.15746976.2010.00213.x

10. Shivaji S, Prakash J. How do bacteria sense and respond to low temperature?. Arch Microbiol. 2010; 192(2): 85-95. doi.org/10.1007/s00203-009-0539-y

11. D'Amico S et al. Psychrophilic microorganisms: challenges for life. EMBO rep. 2006; 7(4): 385-389. doi.org/10.1038/ sj.embor.7400662

12. Batarilo I et al. Results of Microbiological Environmental Monitoring of Blood Production Department in Croatian Institute of Transfusion Medicine. Regional Congress of Internationa Society of Blood Transfusion. 2011.

13. Cantarelli WV et al. Quality control for microbiological culture media: Is it enough to follow the NCCLS M22A2 procedures?. Braz J Microbiol. (2003); 43: 8-10. doi. org/10.1590/S1517-83822003000500003

14. Đurđević-Milošević D et al. Comparison of Two Microbiological Methods After Swabbing in Surface Hygiene Control. II International Congress Food Technology, Quality and Safety. 2014.

15. Nagarajan $P$, Mahalingam $P$, Aasaithambi A. Think before use: Sterility checking of culture plates. GSC Biological and Pharmaceutical Sciences. 2018; 5(1): 82-86. doi. org/10.30574/gscbps.2018.5.1.0094 


\section{THE IMPORTANCE OF CHECKING THE STERILITY OF THE NUTRIENT MEDIA FOR THE IDENTIFICATION OF MICROORGANISMS BEFORE USE IN THE MICROBIOLOGICAL LABORATORY}

1 Adis Hrvačić

1 The Institute for Public Health of Central Bosnia Canton

\section{Abstract

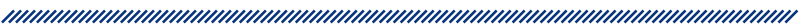

Microbial contamination of the nutrient media used for the cultivation of microorganisms is quite common in microbiology laboratories. During the preparation of nutrient media for the cultivation and isolation of pure bacterial cultures, the likelihood of contamination is high either due to inadequate sterilization, improper handling or inadequate control of storage conditions and to check shelf life. Prepared plates should not be used immediately or stored at low temperature until they are tested for sterility. Sterility testing is a very important segment prior to the use of microbial plates and procedures and one of the major factors affecting the validity of test results in a microbiology laboratory.

The aim of the paper is to establish criteria for rejection of contaminated plates. Three sets of plates of nutrient medium were prepared and incubated at room temperature for 18-24 h to check for sterility. Contamination assessment: colony growth on or below the surface. Plate incubation was extended by another day for the development of contamination on plates on which no colonies had grown on day one.

The results revealed that two types of contamination were found in the two groups. The first set of plates had colonies on the surface and contamination was not found the next day on uncontaminated plates indicating that contamination could occur during improper handling of the plates. The second group has colonies below the surface and pollution developed on the second day in non-contaminated plates due to improper sterilization of glassware or improper sterilization of nutrient media.

Understanding the importance of sterility testing before using nutrient media for the cultivation of microorganisms of interest, it is recommended that sterility confirmed plates be used for further microbiological procedures, while all other sets of contaminated plates establish rejection criteria regardless of how they are produced and what type of contamination is found.

Keywords: microbiological contamination, sterility, microorganisms, laboratory 